\title{
CAPITAL ACCOUNT LIBERALIZATION, FREE LONG-TERM CAPITAL FLOWS, FINANCIAL CRISES AND ECONOMIC DEVELOPMENT
}

\author{
Ajit Singh \\ Queens' College, University of Cambridge
}

\section{MAIN ISSUES AND THE INTERNATIONAL POLICY CONTEXT}

The main objective of this paper is to review the theoretical issues and available empirical evidence on capital account liberalization. In addition to being of interest in its own right, capital account liberalizations is important to the debate on the New International Financial Architecture (NIFA) and to the post-Doha agenda at the World Trade Organization (WTO) in relation to foreign direct investment (FDI) flows. This paper focuses on developing countries and it considers policy from the perspective of (a) economic development and (b) the global rules of the game rather than the economic policy within individual countries. The paper essentially examines the question: what kind of global economic order in relation to capital flows can best serve the interests of developing countries?

Capital account liberalization is an area where economic theory is the most disconnected from real-world events. In analyzing liberalization of capital flows, it is customary to distinguish between short-term (for example, portfolio flows and shortterm bank loans) and long-term flows (for example, FDI). Neoclassical theory suggests that free flows of external capital (including short-term capital) should be equilibrating and help smooth a country's consumption or production paths. However, in the real world, exactly the opposite appears to happen. Liberalization of the shortterm capital account has invariably been associated with serious economic and financial crises in Asia and Latin America in the 1990s. The proponents of neoclassical theory argue that the case for free capital flows is no different from that for free trade; the former could simply be regarded as a form of inter-temporal trade. The first part of the paper addresses this central controversy in relation to developing countries and specifically asks the following questions:

- To what extent, if any, are trade liberalization and free capital flows analogous in their effects on social welfare? What are the conditions necessary to maximize their potential net benefits?

- What is the nature of the relationship between capital account liberalization and economic crises?

- Why do such crises occur far more in developing than in advanced countries?

Ajit Singh: Queens' College, University of Cambridge, Cambridge, CB3 9ET, United Kingdom. Email: as14@econ.cam.ac.uk

Eastern Economic Journal, Vol. 29, No. 2, Spring 2003 
- Do free capital flows lead to faster long-term economic growth, which may compensate for the crisis and the economic instability associated with capital account liberalization?

- What kind of multilateral framework, if any, would be most appropriate for regulating international capital flows that would best serve the interests of developing countries?

In the light of the recent deep economic and financial crises in Asia, Latin America and Russia, many (but by no means all) economists today accept that because shortterm capital flows are often volatile and subject to surges and sudden withdrawals, these flows could have seriously adverse consequences for developing countries. However, long-term capital flows, particularly FDI, are regarded as being much more stable, and for this and other reasons, are thought to have a positive influence on long-term economic development. It is therefore suggested that when liberalizing their capital account, developing countries may wish to liberalize only long-term capital flows such as FDI in the short- to medium-term, while still partially or wholly controlling short-term flows.

Even Joseph Stiglitz, who has been a fierce critic of precipitate capital account liberalization in developing countries, appears to favor free FDI flows. Thus Stiglitz finds striking "the zeal with which the International Monetary Fund (IMF) had requested an extension of its mandate to include capital market liberalization a short two years earlier at the Annual Meetings in Hong Kong. It should have been clear then, and it is certainly clear now, that the position was maintained either as a matter of ideology or of special interests, and not on the basis of careful analysis of theory, historical experience or a wealth of econometric studies. Indeed, it has become increasingly clear that there is not only no case for capital market liberalization, but that there is a fairly compelling case against full liberalization" [2000, 1076]. Stiglitz, however, emphasizes that his general strictures against capital account liberalization are primarily directed against short-term speculative flows. He writes, "The argument for foreign direct investment, for instance, is compelling. Such investment brings with it not only resources, but also technology, access to markets, and (hopefully) valuable training, an improvement in human capital. Foreign direct investment is also not as volatile-and therefore as disruptive-as the short-term flows that can rush into a country and, just as precipitously, rush out" [ibid., 1076].

This paper takes major issue, with the orthodox laissez-faire position [Summers, 2000; Fischer, 2001], of the desirability of speedy capital account liberalization in developing countries. It does, however, also part company with Stiglitz in important respects. I argue that although Stiglitz is right in suggesting that free-trade in capital is not the same as free trade in goods, he implicitly assigns too much virtue to the latter. I make this argument more in global economic terms rather than in those of the traditional concepts, such as infant industry protection. I further suggest that not only do developing countries need controls against short-term capital flows for many of the reasons Stiglitz puts forward, but they also require discretion to regulate FDI flows if it is thought to be desirable. This paper also argues that free movements of even FDI may contribute to financial fragility in developing economies and also may not serve the cause of economic development in a number of other ways. 
These issues of capital account liberalization are, of course, not only of academic interest, but clearly of serious policy concern for developing countries. Note that the present paper concentrates exclusively on the international dimension of the policy debate on the subject. Orderly and fast progress toward capital account liberalization for all countries has been at the heart of the proposals by G7 countries for the New International Financial Architecture (NIFA). Similarly, the European Union and Japan have raised the question of the free movements of FDI as an important subject for study and eventual negotiations at the WTO. Unlike the aborted OECD Multilateral Agreement on Investment, these new proposals wholly exclude shortterm capital flows and focus entirely on FDI. To date, these proposals have received little academic or public attention. Now, following the Doha WTO Ministerial Declaration, these issues are on the international agenda and merit urgent scrutiny. There is already a large literature on the NIFA. ${ }^{1}$ However, the advanced countries' proposal for the free movement of FDI has not been studied much. The second half of the paper redresses this imbalance by focusing on FDI flows, specifically on the proposed new multilateral agreement on such flows.

To sum up, the main contribution of this paper lies firstly in bringing together the relevant theory and empirical evidence from diverse areas (theory of international trade, of international factor movements, of industrial organization, of finance, and of economic development) to bear on important international economic policy issues with respect to both short-term and long-term capital flows to developing countries. Secondly, the paper examines these multilateral arrangements entirely from a developing country perspective. Thirdly, it provides analysis and evidence to suggest that even unfettered FDI, a capital inflow favored by most economists, may not serve the developmental needs of many countries. Fourthly, the paper provides a critical analysis of the proposed new multilateral agreement (PMAI) being put forward at the WTO by some advanced countries. As mentioned above, very little work has been done on this specific topic before.

\section{FREE TRADE VERSUS FREE CAPITAL MOVEMENTS: ARE THEY ANALOGOUS? ${ }^{2}$}

\section{Free Trade and Economic Openness: Analytical Considerations}

The traditional case for free trade can best be put in terms of the two fundamental theorems of welfare economics. According to the first welfare theorem, a competitive equilibrium in the absence of externalities and non-satiation constitutes a Pareto optimum. The second theorem, which is more relevant for present purposes, states that any Pareto optimum can be realized as a competitive equilibrium in the presence of all-around convexity, provided suitable lump-sum transfers can be arranged among the participants. Most of these assumptions are erroneous or are not easily met in the real world. Nevertheless, neoclassical economists suggest that such considerations do not destroy the case for free trade; they only change the nature of the argument. Thus, Krugman concludes his classic defense of free trade in terms of modern theory as follows: "this is not the argument that free trade is optimal because 
markets are efficient. Instead it is a sadder but wiser argument for free trade as a rule of thumb in a world whose politics are as imperfect as its markets" [1987, 143].

However, as Chakravarty and Singh [1988] suggest, the politics of a world of increasing returns to scale are more likely to gravitate towards managed rather than free trade. Instead of either free trade or autarchy, this would be a world in between-a world of trade restrictions, government assistance to favored industries, and a plethora of special arrangements between countries, in other words, the messy real world. In place of all-around convexity, this real world is characterized by learning by doing [Arrow, 1962], dynamic economies and cumulative causation [Young, 1928; Kaldor 1978]. This is, therefore, the world of second best and of multiple equilibria. The purpose of policy is to move from a bad to a good equilibrium. The gains from such policy intervention, however, have to be balanced against the losses from government failure. Appropriate policy can therefore be prescribed only on a case-bycase basis [Occampo and Taylor, 2000; Gomery and Baumol, 2000]. Provided a mechanism exists to ensure full employment of each nation's resources, and if we abstract, for the moment, from the possibility of government failure, a policy of selective economic openness would be a source of great advantage for an economy for any one of the following reasons: ${ }^{3}$

(a) it may enable a country to concentrate its relatively specialized resources in areas of production where the world demand is highly income and price elastic;

(b) it may lead to diffusion of knowledge of a nature which can lead to considerable upgrading of the quality of local factors of production;

(c) it may lead to sufficient competitive pressure to eliminate X-inefficiency;

(d) trade may lead to changes in the distribution of income which can lead to a greater share of accumulation in national income;

(e) trade may facilitate what Schumpeter stressed so much: an accelerated process of creative destruction.

In general, trade openness works positively if the phenomenon of "learning" from contacts with the rest of the world is institutionalized through suitable adaptations on the policy side involving appropriate government interventions which make the domestic economy more responsive to change. This is a main lesson that emerges from the outstanding industrial success of East Asian economies during the second half of the $20^{\text {th }}$ century. ${ }^{4}$ Countries such as Japan and Korea established comprehensive technology and industrial policies to institutionalize such learning. It is important to appreciate that although Japan and Korea were "trade open" in the sense of being export or outward oriented, they were not so open on the side of imports. Both countries maintained, formally or informally, selective import controls for long periods during the course of their industrialization. The strategic interests of the U.S. hegemony permitted such selective openness without threatening retaliation. ${ }^{5}$ To pursue these policies of selective economic openness, it is necessary for developing countries to have not only appropriate institutions to minimize the incidence of government failure, but also a world conjuncture that permits them to pursue commercial and industrial policies on a non-reciprocal basis that best suits their developmental requirements. Chakravarty and Singh [1988] point out that in such a world, 
selective economic openness may be a superior strategy than either free trade or autarchy. They also suggest that at a theoretical level, learning over time is a more relevant paradigm for developmental gains from trade than the neoclassical story that emphasizes the exploitation of arbitrage opportunities. ${ }^{6}$

To sum up, while the classical and neoclassical arguments for free trade suffer from serious conceptual and operational difficulties, selective trade or economic openness have substantive benefits that are more robust than the traditional neoclassical theory suggests. Such benefits can be realized, however, only in a world conjuncture in which full employment and other structural conditions outlined above are met, coupled with an appropriate set of domestic policies that go considerably beyond the limits of commercial policy as traditionally defined.

\section{The Case for Capital Account Liberalization}

The case for capital account liberalization was authoritatively put forward by Stanley Fischer, the former Deputy Managing Director of the International Monetary Fund, in the following terms:

- that the benefits of liberalizing the capital account outweigh the potential costs;

- that countries need to prepare well for capital account liberalization: economic policies and institutions, particularly the financial system, need to be adapted to operate in a world of liberalized capital markets; and

- that an amendment of the IMF's Articles of Agreement is the best way of ensuring that capital account liberalization is carried out in an orderly, non-disruptive way, that minimizes the risks that premature liberalization could pose for an economy and its policymakers. [1997]

Fischer suggests that, at a theoretical level, capital account liberalization would lead to global economic efficiency, allocation of world savings to those who are able to use them most productively, and would thereby increase social welfare. Citizens of countries with free capital movements would be able to diversify their portfolios and thereby increase their risk-adjusted rates of return. It would enable corporations in these countries to raise capital in international markets at a lower cost. It is suggested, moreover, that such liberalization leads to further development of a country's financial system, which in turn is thought to enhance productivity in the real economy by facilitating transactions and by better allocating resources. Some argue that free capital movements will help increase world welfare through another channel, namely transferring resources from aging populations and lower rates of return in advanced countries to younger populations and higher rates of return in newly industrializing economies. Such resource transfers will be Pareto optimal as both rich and poor countries would gain.

Summers succinctly sums up the core point of the orthodox perspective as follows: “... the abstract argument for a competitive financial system parallels the argument for competitive markets in general ... Just as trade in goods across jurisdictions has benefits, so too will intertemporal trade and trade that shares risks across jurisdictions have benefits" [2000, 2]. 
Orthodox economists recognize that capital account liberalization has risks. Markets sometimes overreact or react late or react too fast. However, Fischer argues that “...capital movements are mostly appropriate: currency crises do not blow up out of a clear blue sky, but rather start as rational reactions to policy mistakes or external shocks. The problem is that once started, they may sometimes go too far" [1997, 4-5]. In general, Fisher believes that capital markets serve as an important discipline for government macroeconomic policy "which improves overall economic performance by rewarding good policies and penalizing bad." [ibid., 4]

Two initial observations may be made with respect to this orthodox case for capital account liberalization. The first is that not all orthodox economists favor such liberalization. Bhagwati [1998] for example, a leading theorist and advocate of free trade in goods and services, regards capital account liberalization as inappropriate for developing countries. Secondly, as with the case of the neoclassical argument for free trade, the maintenance of full employment and macroeconomic stability constitute an important prerequisite for reaping the benefits of a globalized capital market. Specifically, as Rakshit [2001] suggests, the theoretical model of the beneficial effects of free capital movements makes the following assumptions:

(a) resources are fully employed everywhere;

(b) capital flows themselves do not stand in the way of attaining full employment or macroeconomic stability; and

(c) the transfer of capital from one country to another is governed by long-term returns on investment in different countries.

The validity of these assumptions under the current global economic regime is examined below.

\section{The Analytical Case Against Free Capital Flows}

The theoretical case against the view that unfettered capital movements are essential for maximizing the gains from trade and world economic welfare has been made by a number of economists from different schools of thought. First within the neoclassical tradition itself, Stiglitz [2000] argues that the concept of free movements of capital is fundamentally different from that of free trade in goods. Capital flows are subject to asymmetric information, agency problems, adverse selection, and moral hazard. Although such problems may occur also in trade in goods and services, they are intrinsic to financial flows and are far more significant.

Importantly, there are also diverging views about the price formation process in asset markets such as the stock market and the currency markets. Orthodox economists subscribe to the theory of efficient markets. In this view, prices are a collective outcome of actions of a multitude of individual economic agents whose behavior is assumed to be based on utility maximization and rational expectations. This price formation process is thought to lead to efficient prices in these markets. A powerful counter-view is that put forward by Keynes [1936] in Chapter 12 of the General Theory 
and encapsulated in his well-known "beauty contest" analogy, which highlights the role of speculation in determining prices.

Thus, in Keynesian analysis, which has been formalized in recent theoretical contributions, price formation in asset markets may often be dominated by speculators or, in modern parlance, noise traders. Moreover, theoretical work on Darwinian selection mechanisms indicate that the Friedman [1953] assertion that rational investors will always wipe out speculators is far from being valid in all situations. ${ }^{7}$

Further the critical school emphasizes that financial markets are particularly prone to coordination failures and often generate multiple equilibria, some of which are good and some of which are bad. In the absence of appropriate coordination by the government or international authorities, an economy may languish in a low-level equilibrium, producing suboptimal output and employment levels.

The post-Keynesian economists [see for example, Davidson, 2001], take a more radical stance. They put forward analyses and evidence in favor of Keynes' thesis "that flexible exchange rates and free international capital mobility are incompatible with global full employment and rapid economic growth in an era of multilateral free trade" [ibid., 12]. These economists also challenge the orthodox presumption that transparency and availability of more information would make the financial markets less prone to crisis. They point out that the crises are fundamentally due to the fact that the future is uncertain and people have different perceptions about it.

Keynes was very skeptical about the ability of the world economy under free trade and free capital movements to maintain balance of payments equilibrium between countries at full employment levels of output. In a famous passage he observed, “... the problem of maintaining equilibrium in the balance of payments between countries has never been solved ... the failure to solve the problem has been a major cause of impoverishment and social discontent and even of wars and revolutions ... to suppose that there exists some smoothly functioning automatic mechanism of adjustment which preserves equilibrium only if we trust to matters of laissez faire is a doctrinaire delusion which disregards the lessons of historical experience without having behind it the support of sound theory" [Moggridge, 1980, 21-2]. Consequently the Keynesian design for the postwar international financial system did not envisage free capital movements.

In summary, the orthodox theory that financial liberalization leads to global economic efficiency based on the analogy with free trade is flawed on several counts, including some within the neoclassical tradition itself.

\section{EMPIRICAL RESEARCH ON FINANCIAL LIBERALIZATION AND ECONOMIC CRISIS}

\section{Banking and Currency Crises and the Real Economy}

The theoretical expectation that free capital movements lead to smoother income and consumption trajectories for individuals and countries following economic shocks than would otherwise be the case, has been confounded by the experience of developing countries. Substantial empirical evidence suggests a close link between the liber- 
alization of the financial system and economic and financial crises particularly in developing countries. Developed countries, including the United States, the UK and Scandinavian countries, have also been subject to such crises, but compared with developing countries, the incidence has been relatively low and the social costs correspondingly smaller. However, developing countries have suffered not only more but also deeper crises and virtual financial meltdowns.

Compared to this impressionistic evidence, the results of detailed econometric studies are more mixed. The empirical literature on this subject is vast and still growing at a fast rate. At least four kinds of studies are relevant. First, contributions to the financial literature support the orthodox case that financial liberalization in emerging markets reduces the cost of equity capital and has a positive impact on domestic investments. [Bekaert, Harvey and Lundblad, 2001; Henry 2000; Chari and Henry, 2002]. Secondly, studies on financial liberalization, banking, and currency crisis find that there is a close causal relationship between these variables, thus providing support for the anti-liberalization camp. Some of these studies will be reviewed below. A third strand of this literature concerns financial crashes and suggest that financial liberalization is much more risky in this respect for developing than for advanced countries. Leading contributions in this area are Martin and Rey [2002]. Wyplosz [2001], Mendoza [2001], McKinnon and Pill [1999]. The fourth part of this literature considers the relationship between capital account liberalization and long-term economic growth.

It is not our purpose here to systematically review this whole body of literature but rather to draw relevant conclusions for a multilateral global framework for shortand long-term capital flows from a developing country perspective. However, in order to indicate the nature and the kind of evidence produced by these studies, a few of them will be briefly examined below.

Kaminsky and Reinhart's [1999] paper explored the links between banking crises, exchange rate crises, and financial liberalization. The sample covered 1970 to 1995 and consisted of twenty countries, fourteen of which were developing. The authors found that both types of crises increased sharply since 1980. The average number of banking crises in their sample rose from 0.3 per year from 1970 to 1979 to 1.4 per year from 1980 to 1995 . The two authors found that the banking crises and the currency crises are closely related and that the banking crises are often preceded by financial liberalization.

In their influential study Demigüc-Kunt and Detragiache [1998] examined banking crises from 1980 to 1984 for a sample of 53 developed and developing countries. They found that a banking crisis is more likely to occur where the financial system has been liberalized. They also found a two-way interaction between banking and currency crises. Where the banking systems are not sufficiently developed, with capital account liberalization, banks become vulnerable to external economic shocks. The authors' findings suggest that vulnerability is reduced with institutional development and strengthening of the banking system through prudential regulation. They also found that financial liberalization leads to an intensification of competition among banks and hence to greater moral hazard and risk-taking than before. ${ }^{8}$ 
The recent Asian crisis provides almost a laboratory experiment for examining the role of capital account liberalization in causing or exacerbating that region's severe economic downturn. Williamson and Drabek [1998] provide evidence to suggest that countries that did or did not have economic crises were differentiated only by whether or not they had liberalized their capital accounts. Most economists would now agree that even if premature financial liberalization without adequate prudential regulation was not the root cause of the crises in countries such as Thailand, Korea, and Indonesia, it greatly contributed to the occurrence and depth of the crises. Indeed, the economic fundamentals prior to the crises of the affected countries were better than those of India, but the latter country was spared the crisis because of its control over the capital account. Similarly, China managed to avoid a crisis and continued to have fast economic growth. China also had not liberalized its capital account. ${ }^{9}$

It is argued by some that even with the acute economic crisis of 1998-1999, over the long run Korea, with its economic openness, was a much more successful economy than India. This argument has some plausibility but overlooks the crucial fact that Korea's outstanding industrialization record over the previous three decades was not accomplished by a liberalized financial system but rather by a highly controlled one. However, when the system was liberalized in the 1990s it was followed by an unprecedented crisis [Demetriades and Luintel, 2001].

\section{Social and Economic Costs of the Crisis}

The Asian crisis was extremely important in terms of its economic and social impact on the populations of the affected countries. The World Bank notes that "In terms of lost output and the implications for poverty and unemployment, the Asian crisis represents one of the most acute periods of financial instability in this century" $[2001,73]$. The crisis greatly increased poverty, reduced employment and real wages, and caused enormous social distress. Indeed the economic downturn was so enormous that in a country like Indonesia the social fabric of the country virtually disintegrated. This is why the Asian crisis is aptly termed, not just an ordinary slowing of GDP growth due to an economic shock or a normal cyclical recession, but an enormous meltdown. It is important to appreciate, however, that even if no meltdown occurs, economic slowdowns or recessions have bigger social costs in developing than developed countries because of their lack of publicly provided social security. There is evidence that in both country groups the effects of a downturn fall disproportionately on the poor and on women [Singh and Zammit, 2000; Stiglitz, 1999; World Bank, 1998/99].

Turning to an investigation of purely economic costs, there are good analytical reasons to believe that economic crises would negatively affect both investment and long-term growth [Pindyck, 1991; World Bank [2001]; Easterly et al., 2000]. In addition, recessions and meltdowns also have fiscal and redistributive implications that may affect the economy for a long period of time. Caprio and Klingebiel [1996] estimates indicate that the costs of a banking crisis are typically quite large, ranging from 3.2 percent of GDP in the 1984-91 U.S. savings and loans crisis to 55.3 percent 
TABLE 1

Fiscal Costs of Banking Crisis in Selected Countries (percentage of GDP)

\begin{tabular}{llc}
\hline Country & Date & Cost as a percentage of GDP \\
\hline Argentina & $1980-82$ & 55.3 \\
Chile & $1981-3$ & 41.2 \\
Uruguay & $1981-4$ & 31.2 \\
Israel & $1977-83$ & 30.0 \\
Cote d'Ivoire & $1988-91$ & 25.0 \\
Senegal & $1988-91$ & 17.0 \\
Spain & $1977-85$ & 16.8 \\
Bulgaria & $1990 \mathrm{~s}$ & 14.0 \\
Mexico & 1995 & 13.5 \\
Hungary & $1991-95$ & 10.0 \\
Finland & $1991-93$ & 8.0 \\
Sweden & 1991 & 6.4 \\
Sri Lanka & $1989-93$ & 5.0 \\
Malaysia & $1985-8$ & 4.7 \\
Norway & $1987-89$ & 4.0 \\
United States & $1984-91$ & 3.2 \\
\hline
\end{tabular}

Source: Caprio and Klingebiel 1996. Quoted in Chang, (2001)

for the 1980-82 Argentinian banking crisis (Table 1). On the basis of more recent evidence, Aizenman [2002] estimates the average cost of a currency crisis to be 8 percent of the pre-crisis GDP and the average cost of a simultaneous banking and currency crisis is 18 percent of pre-crisis GDP. He also reports that "the twin crises are mainly concentrated in financially liberalized emerging market economies" [ibid., 5].

In a pioneering study Easterly et al. [2000] investigated economic instability for a large cross-section of developed and developing countries from 1960 to 1990 . As Table 2 indicates, developing countries typically suffer greater instability than developed countries with respect to output, employment, real wages, capital flows and terms of trade changes. ${ }^{10}$ In neoclassical analysis it is customary to attribute instability to the lack of flexibility in labor markets, particularly to wage rigidity. However, Easterly et al. find that despite greater labor market flexibility (measured by changes in real wages) in developing countries, wages are also more volatile than developed countries (Table 2). The authors' results suggest that the characteristics of the financial system rather than the labor market are the more important causes of economic instability. ${ }^{11}$ Their econometric analysis shows that financial variables are statistically significant in explaining both volatility of GDP growth and the likelihood of a downturn. They find that openness and policy volatility also have a significant influence on growth volatility. In general, the findings of Easterly et al. suggest that countries with weak financial systems display greater instability in GDP growth in part because these institutional shortcomings amplify the effects of the volatility of capital flows. 
TABLE 2

\section{Economic Instability and Related Variables: Differences between Developing and High-Income OECD Countries}

\begin{tabular}{|c|c|c|c|c|c|c|}
\hline \multirow[b]{2}{*}{ Variable } & \multicolumn{2}{|c|}{ Developing Countries } & \multicolumn{4}{|c|}{ High-income OECD Countries } \\
\hline & Mean & $\begin{array}{c}\text { Number of } \\
\text { observations }\end{array}$ & Mean & $\begin{array}{c}\text { Number of } \\
\text { observations }\end{array}$ & $\begin{array}{l}\text { t-Statistic for } \\
\text { difference } \\
\text { in means }\end{array}$ & $\mathrm{P}$-value \\
\hline Growth & 0.007 & 163 & 0.027 & 23 & -5.659 & 0.000 \\
\hline $\begin{array}{l}\text { Standard deviation } \\
\text { of growth }\end{array}$ & 0.061 & 163 & 0.026 & 23 & 9.779 & 0.000 \\
\hline $\begin{array}{l}\text { Median standard } \\
\text { deviation of growth }\end{array}$ & 0.052 & & 0.022 & & & \\
\hline $\begin{array}{l}\text { Standard deviation } \\
\text { of employment }\end{array}$ & 0.098 & 83 & 0.035 & 21 & 6.652 & 0.000 \\
\hline $\begin{array}{l}\text { Standard deviation } \\
\text { of real wage index }\end{array}$ & 2.119 & 90 & 1.883 & 21 & 0.833 & 0.410 \\
\hline $\begin{array}{l}\text { Standard deviation } \\
\text { of real wage changes }\end{array}$ & 1.197 & 85 & 0.321 & 21 & 8.116 & 0.000 \\
\hline $\begin{array}{l}\text { Private capital } \\
\text { flows / GDP }\end{array}$ & 1.722 & 146 & 0.372 & 22 & 2.743 & 0.009 \\
\hline $\begin{array}{l}\text { Standard deviation } \\
\text { of private capital } \\
\text { flows / GDP }\end{array}$ & 2.662 & 138 & 2.311 & 22 & 0.808 & 0.420 \\
\hline $\begin{array}{l}\text { Standard deviation } \\
\text { of terms of trade } \\
\text { changes }\end{array}$ & 0.123 & 117 & 0.041 & 23 & 9.688 & 0.000 \\
\hline $\begin{array}{l}\text { Standard deviation } \\
\text { of money growth }\end{array}$ & 0.219 & 148 & 0.077 & 20 & 6.757 & 0.000 \\
\hline
\end{tabular}

Source: Easterly, W, Islam, R. and Stiglitz, J.E. [2000].

\section{Capital Account Liberalization and Proximate Causes of Instability}

The fundamental theoretical reasons why capital account liberalization may lead to economic instability were analyzed earlier. The present subsection briefly reviews some of the proximate reasons for this instability in developing countries, namely:

(a) Self-fulfilling expectations;

(b) volatility in capital flows;

(c) Increased competition among banks following liberalization as mentioned above;

(d) The changes in the global financial system and the short-termism of the leading players.

Self-fulfilling expectations. A large literature based on the self-fulfilling expectations suggests that capital account liberalization is much more likely to lead to financial crisis in emerging markets than in developed countries. This literature points to the role of factors such us moral hazard, credit constraints and overborrowing syndrome as factors to explain these different outcomes. Martin and Rey [2002), an 
important contribution to these studies, provide empirical evidence that after liberalization the probability of a financial crisis is negatively related to per capita income, whereas before liberalization these variables are only weakly related. The authors report that the results are robust to alternative definitions of financial crash. Their model of self-fulfilling expectations does not require any appeal to special factors mentioned above to explain these empirical facts. Rather, in their model, for intermediate levels of international financial transactions costs, pessimistic expectations can be self-fulfilling leading to a financial crash. The crash is accompanied by capital flight, a drop in income below the financial autarchy level, and market incompleteness.

Volatility. The volatility and the procyclical nature of private capital flows to developing countries is a well-attested feature of international capital movements during the last two decades [Williamson, 2002; Occampo, 2001; Singh and Zammit, 2000; Stiglitz, 2000]. Such inflows come in surges, often bearing no relationship to the economic fundamentals of the country, and leave the country when they are most needed; that is in a downturn. As Williamson and Drabek [1998] note, even in a country such as Chile which was deeply integrated with the world financial markets, private foreign capital suddenly withdrew in the event of a fall in copper prices. There is, however, an important debate on the comparative volatility of the different components of capital flows, which will be reviewed in the following sections.

Ramey and Ramey [1995] found that the effects of the volatility of capital flows was positively related to volatility of GDP growth, a result confirmed by Easterly et al. [2000]. The former two authors also reported a negative relationship between long-run economic growth and the volatility of GDP growth, a result again confirmed by Easterly et al. [2000], and also by World Bank [2001], among others. Table 3, from the latter publication, presents regression results of the effects of capital flows and their volatility on growth per capita, for a large sample of developing countries over successive decades, covering the 1970-1998 period. The table also contains the normal control variables used in such cross-section analyses (for example, initial GDP per capita, initial schooling, population growth rate, investment rates, and a measure of policy). Volatility of capital flows is measured by the standard deviation of the flows. The dependent variable is the rate of growth of GDP per capita. The table suggests an economically important and statistically significant negative relationship between capital flow volatility and GDP growth per capita for the 1970-1998 period as a whole. ${ }^{12}$ It is interesting, however, that the negative relationship becomes weaker over time, with the value of the relevant coefficient rising from a statistically significant minus .322 during 1970-79 to minus .124 in 1990-98 when the coefficient was also statistically insignificant. Other results from Table 3 will be commented on in the following section.

The next issue is why the capital flows to developing countries are so volatile. Analysis and evidence suggests that both internal (for example, weak domestic financial systems, and frequent economic shocks) and external factors, particularly the animal spirits of foreign investors, are involved in making these flows volatile.

Kindleberger [1984] has observed that financial markets are subject to frequent crises, which he ascribes to periodic and alternating bouts of irrational exuberance 
TABLE 3

Effects of Capital Flows and Their Volatility on Growth per Capita by Decade.

\begin{tabular}{lcccc}
\hline & \multicolumn{5}{c}{ Dependent Variable: Rate of GDP Growth per Capita } \\
Independent variable & $1970-98$ & $1970-80$ & $1980-89$ & $1990-98$ \\
\hline Capital flows & $0.287^{\mathrm{b}}$ & -0.149 & 0.133 & $0.275^{\mathrm{b}}$ \\
Capital flows volatility & $-0.344^{\mathrm{b}}$ & $-0.322^{\mathrm{b}}$ & -0.188 & -0.124 \\
Initial GDP per capital & $-0.508^{\mathrm{b}}$ & -0.345 & $-0.940^{\mathrm{b}}$ & 0.159 \\
Initial schooling & 1.429 & -1.749 & $3.640^{\mathrm{a}}$ & -0.446 \\
Population growth rate & $-0.513^{\mathrm{b}}$ & -0.438 & $-0.573^{\mathrm{b}}$ & $0.869^{\mathrm{b}}$ \\
Investment & $0.182^{\mathrm{b}}$ & $0.309^{\mathrm{b}}$ & $0.164^{\mathrm{b}}$ & $0.094^{\mathrm{b}}$ \\
Policy & $0.008^{\mathrm{b}}$ & $0.007^{\mathrm{b}}$ & $0.011^{\mathrm{b}}$ & $0.013^{\mathrm{b}}$ \\
Inflation rate & $-0.002^{\mathrm{b}}$ & -0.008 & $-0.001^{\mathrm{b}}$ & $-0.004^{\mathrm{b}}$ \\
Openness of the & & & & \\
$\quad$ economy & 0.001 & 0.006 & 0.001 & $-0.024^{\mathrm{b}}$ \\
& & & & \\
Adjusted $\mathrm{R}^{2}$ & 0.75 & 0.59 & 0.57 & 0.38 \\
No. of Countries. & 72 & 56 & 74 & 100 \\
\hline
\end{tabular}

a. Significant at the 10 percent level

b. Significant at the 5 percent level.

Source: World Bank [2001].

and pessimism of investors largely unrelated to fundamentals. Importantly, Kindleberger's historical analysis is implicitly endorsed by Alan Greenspan, the Chairman of the U.S. Federal Reserve himself, who recently commented on the 1987 U.S. stock market crash and the Asian financial meltdown of the 1990s:

At one point the economic system appears stable, the next it behaves as though a dam has reached a breaking point, and water (read, confidence) evacuates its reservoir. The United States experienced such a sudden change with the decline in stock prices of more than 20 percent on October 19, 1987. There is no credible scenario that can readily explain so abrupt a change in the fundamentals of long-term valuation on that one day. ... But why do these events seem to erupt without some readily evident precursors? Certainly, the more extended the risk-taking, or more generally, the lower the discount factors applied to future outcomes, the more vulnerable are markets to a shock that abruptly triggers a revision in expectations and sets off a vicious cycle of contraction. ... Episodes of vicious cycles cannot easily be forecast, as our recent experience with Asia has demonstrated. [1998, 4-5]

This mirrors the Keynesian view of investor behavior and the significance of mass psychology in price formation in the financial markets, as discussed earlier. Keynes' insights on this subject have been formalized in current theoretical literature, which is able to provide a "rational" explanation for the herdlike behavior, contagion and other irrational manifestations of economic agents in financial markets [Shiller, 2000; Singh and Weisse, 1999; Singh, 1999]. 
It is also important to emphasize another major factor in causing the volatility of external capital flows to developing countries. Kaufman [2000] and Williamson [2002] have stressed the significance of changes in the nature and character of the financial markets in enhancing capital flow volatility. The intense competition in the world fund management industry together with the nature of rewards offered to fund managers have helped to make fund managers focus on the short run when making their investment decisions. ${ }^{13}$ As Kauffman notes:

In the new global financial system, most prominent banks, securities firms, and even a few insurance companies possess departments that emulate the trading and investment approach of the hedge funds. Even the corporate treasuries of a number of non-financial corporations are engaged in this activity. Once arcane and exotic, the hedge fund approach to investment has been mainstreamed. [2000, 61]

Finally, analysis and evidence for increased competition among banks following liberalization is provided by Furman and Stiglitz [1999] and Stiglitz [2000] among others.

\section{EVIDENCE ON CAPITAL ACCOUNT LIBERALIZATION AND LONG- TERM ECONOMIC GROWTH}

In principle it is possible for the instability caused by capital account liberalization to be more than compensated for by faster long-term economic growth arising from the greater availability of capital inflows. This is the promise held by the proponents of this policy regime [Fischer, 1997; Summers, 2000]. It will therefore be useful to review the available empirical evidence on this issue.

A good starting point is the broad brush approach adopted by Singh [1997a] in analyzing this issue. He considers the case of advanced countries whose experience, he suggests, is relevant for developing economies. This is because the former have operated under a regime of relatively free trade and capital movements for nearly two decades - a period long enough to make at least a preliminary assessment of the effects of this economic regime on performance. Evidence suggests that the record has been less than impressive despite the fact that the world economy during this period has not been subject to any abnormal negative shocks like the oil price increases of 1973 and 1979. Indeed, the economic performance of industrial countries during this later period has been much worse than in the earlier period of the 1950s and 1960s when they functioned under a myriad of capital controls.

- GDP growth in the 1980s and 1990s under a liberal regime regarding private capital flows was much lower than that achieved in the "illiberal" and regulated "golden age" of the 1950s and 1960s;

- Productivity growth in the last fifteen years has been half of what it was in the "golden age";

- The critical failure is, however, with respect to employment: 8 million people were unemployed in the OECD countries in 1970, but by the mid 1990s 35 million were unemployed, that is, 10 percent of the labor force. 
Singh's analysis also shows that the poor performance of industrialized countries during the 1980s and 1990s cannot alternatively be ascribed to exogenous factors such as the exhaustion of technological opportunities, or to labor market imperfections. Industrial economies have more flexible markets today than they did in the golden age. In addition they have the benefit of a new technological paradigm of information and communication technology which many economic historians regard as on a par with the most important technological revolutions of the last two centuries. In view of all these factors-a new technological paradigm, more flexible markets, absence of economic shocks such as the oil shocks of 1973 and 1975-orthodox analyses would suggest that OECD economies should be growing today at a much faster rate than in the golden age. But as we see the opposite has been true.

Eatwell's [1996] and Singh's [1997a] analyses indicate that the poor performance of industrial countries in the recent period is closely linked to intrinsic features of the liberal financial regime. Coordination failures have led to suboptimal levels of the OECD and world aggregate demand, output and employment. When capital flows were regulated in the 1950s and 1960s, and there was successful coordination under the hegemony of the United States, balance of payments between countries was achieved at much higher levels of output and employment than has subsequently been the case under financial liberalization.

In contrast with the above broad brush approach, there exist numerous econometric studies of the effects of capital account liberalization on economic growth with definitely mixed results. Loungani recently reviewed the IMF contributions on the subject and reached the following conclusion:

.....What impact do capital flows have on growth? The evidence is decidedly mixed and appears to depend, somewhat, on the particular flow studied (or the measure of capital market openness used), the sample period, the set of countries, and whether cross-section or panel data is used. Recent IMF work provides an illustration of mixed findings. In a much-cited study, Borensztein, De Gregorio, and Lee [1998] find that FDI increases economic growth when the level of education in the host country-a measure of its absorptive capacity- is high. Mody and Murshid [2002] find that capital inflows boost domestic investment almost one-to-one, but the strength of this relationship appears to be weakening over time. In contrast, Edison, Levine, Ricci, and Slok [2002], using the new measures of openness, do not find evidence of a robust link between international financial integration and economic growth. [2002, 6]

Two main conclusions emerge from the above review of empirical evidence on capital account liberalization, financial crisis, and GDP growth. First, there is strong evidence of a close relationship between liberalization and economic and financial crises in developing countries. This relationship is robust, and in the circumstances of these countries there are also strong analytical arguments for both its existence and robustness. Secondly, available evidence for the view that free capital flows promote faster long-term economic growth in developing countries is much weaker. 
Aizenman reaches a broadly similar conclusion: “.....there is solid evidence that financial opening increases the chance of financial crisis. There is more tenuous evidence that financial opening contributes positively to long-run growth" [2002, 2] However, from the perspective of economic policy an important consideration is how to proceed from the short to the long term. The economic crises, and the instability that capital account liberalization is seen to generate in the short term, may compromise a country's future economic development by inducing capital flight and lowering domestic investment and long-term economic growth. In summary, in view of these facts and analyses, Stiglitz [2000] is fully justified in castigating the IMF for promoting universal capital account liberalization when most developing countries were not ready for such policies. Fortunately, in the wake of the Asian crisis the IMF has in the most recent period moderated its stance in this respect.

\section{CAPITAL ACCOUNT LIBERALIZATION AND FDI ${ }^{14}$}

As explained in the introduction, while Stiglitz finds a "compelling" case against any general liberalization of the capital account, he also suggests that there is a "compelling" case in favor of FDI. In view of the fickleness of the short-term capital flows and the gyrations of the markets, he comprehensively rejects the argument that capital account liberalization is desirable because it imposes discipline on countries by forcing them to follow good economic policy. However, he states that "far more relevant for the long run success of the economy is the foreign direct investment and the desire to acquire and sustain FDI provide strong discipline on the economy and the political process " [ibid., 1080]. Although he does not specifically address this issue, Stiglitz comes close to accepting the principles of the new proposal that is being put forward by the EU and Japan at the WTO for a multilateral agreement on investment (hereafter PMAI), covering only FDI. The background to this proposal is as follows. Three years ago the OECD countries failed to negotiate a Multilateral Agreement on Investment (MAI) among themselves, which was intended to be acceded to later by developing countries. PMAI is similar to MAI with the critical difference that, unlike the latter, the former will only be confined to FDI. This clearly represents a significant concession to developing countries. The advanced countries' preference would seem to be to establish a binding treaty at the WTO that would create a regime for FDI similar to that of (free) trade in goods. Since this agreement would be based on WTO's basic concepts, previous history suggests that it is likely to include the following kinds of elements:

- the right of establishment for foreign investors (the concept of market access);

- the principle of most-favored nation treatment;

- the principle of national treatment;

- investment protection, including matters relating to expropriation and the transfer of capital;

- additional disciplines relating to, among other matters, entry, stay, and work of key personnel;

- prohibition of performance requirements on foreign investors; 
- rules on investment incentives;

- binding rules for settling disputes through the WTO dispute settlements mechanism. ${ }^{15}$

In favoring FDI Stiglitz seems to be a part of a general consensus among economists that suggests that compared with debt and portfolio investment, FDI, apart from its other merits, is the safest source of funds for developing countries. It neither adds to a country's debt, nor (being bricks and mortar) can it be quickly withdrawn from the country. Further, in view of the other virtues of FDI in bringing new technology, organizational methods, and, importantly, spillovers to domestic industry, its proponents claim that the case for PMAI becomes overwhelming.

Those propositions will be contested below and it will be argued that unfettered FDI is not in the best interests of many developing countries. As with short-term flows, FDI also requires appropriate regulation by these countries to enhance social welfare. Because such measures would be denied by PMAI, poor countries should resist the proposed agreement.

I begin this analysis by noting that developing countries' perspective on, and attitude towards, FDI has changed. In the 1950s and 1960s, developing countries were often hostile towards multinational investment and sought to control multinational companies' activities through domestic and international regulations. During the last two decades, however, emerging countries have been falling over themselves to attract as much multinational investment as possible.

This enormous shift in developing countries' stance toward multinational investment is associated with major changes that have occurred in the pattern of international capital flows to developing counties. The former may be regarded as both a cause and a consequence of the latter. The most important change in capital flows for the purpose of this paper is the emergence of FDI as a predominant source of external finance for developing countries during the 1990s. Between 1996 and 1998 FDI inflows to developing countries constituted about 10 percent of their gross capital formation. [Singh, 2001; UNCTAD, 2001]. It is also important to note that alongside these changes in the pattern of external finance, analysis and evidence suggest that developing countries' need for external finance has greatly increased. This is in part due to the liberalization of trade and capital flows in the international economy. UNCTAD [2000] suggests that because of these structural factors, developing countries have become more balance-of-payments constrained than before: the constraint begins to bite at a much slower growth rate than was the case previously in the 1970s and 1980s.

In these circumstances it is not surprising that developing countries have radically changed their attitude towards FDI. These counties, therefore, have competed intensely to attract FDI. This competition has resulted in a shift in the balance of power towards multinationals. An important objection to PMAI is that if approved, it would worsen this imbalance because the Agreement would essentially give the multinationals a license to (or not to) invest wherever or whenever they like regardless of the circumstance and needs of developing countries. 


\section{FDI AND FINANCIAL FRAGILITY}

Leaving aside other characteristics of FDI (to be discussed later), we will consider it first simply as a source of finance, and examine its implications for balance of payments and macroeconomic management of the economy. In contrast to portfolio investments, FDI, because it involves normally a stake of 10 percent or more in a host country enterprise together with managerial control, is by definition supposed to reflect a long-term commitment. ${ }^{18}$ The presumption is that the inflow of foreign capital in this form will be more stable than portfolio investments, which investors can easily liquidate following an internal or external shock.

There are, however, important arguments to suggest that the presumption of stability in net FDI inflows may not be correct. First, the distinction between FDI and portfolio investment has become much weaker with the growth of derivatives and hedge funds. As Claessens et al., [1995] observe, even at an elementary level it is easy to see how a long-term "bricks and mortar" investment can be converted into a readily liquid asset. They note that a direct investor can use his/her immovable assets to borrow in order to export capital and thereby generate rapid capital outflows.

Another reason why FDI may be volatile is because a large part of a country's measured FDI according to the IMF balance of payments conventions usually consists of retained profits. Profits are affected by the business cycle, and therefore display considerable volatility. This also prevents FDI from being countercyclical and stabilizing unless the host and home country economic cycles are out of phase with each other. That may or may not happen.

Further, there is evidence that, like other sources of finance, FDI flows can also surge at times. Apart from their contribution to volatility, these FDI surges, just like portfolio investment, can lead to equally undesirable consequences such as exchange rate appreciation and reduced competitiveness of a country's tradable sector.

Claessens et al. [1995] concluded that time series properties of the different forms of capital flows including FDI did not statistically differ and that long-term flows were often as volatile as short- term flows. Williamson [2002] has suggested that this study may have failed to find differences between flows because it measured volatility in terms of the second moments of the time series instead of the ones of a higher order. The latter are relevant with respect to occasional meltdowns, which occurred for example in the Asian crisis. UNCTAD's 1998 study of the stability of capital flows between 1992 and 1997 found that FDI was relatively more stable than portfolio flows, with important exceptions including Brazil, South Korea, and Taiwan. ${ }^{17}$ Lipsey [2001] also concluded that the FDI flows were relatively more stable overall.

In favor of the FDI-stability thesis, it has been argued that during the Asian crisis and its aftermath, while bank lending and portfolio flows were sharply reversed, FDI continued much as before. However the motivation for this could have been what Krugman called the "fire-sale" of devalued assets as a result of the crisis. Evidence, however, seems to suggest that it is more likely that the relative stability of FDI is due in part to the fact that the governments abolished regulations preventing or limiting FDI in domestic enterprises (albeit under IMF conditionality in the affected countries). Multinationals have used this opportunity to increase their holdings in local firms at cheap prices [World Bank, 2001]. 
Even if FDI is somewhat less volatile than other flows other important implications of FDI for a host country's balance of payments need to be considered. These derive from the fact that an FDI investment creates foreign exchange liabilities not only now but also into the future. This characteristic leads to the danger that unfettered FDI may create a time profile of foreign exchange outflows (in the form of dividend payments or profits repatriation) and inflows (for example, fresh FDI) which may be time inconsistent. Experience shows that such incompatibility, even in the short run may easily produce a liquidity crisis. The evidence from the Asian liquidity crisis suggests that it could degenerate into a solvency crisis with serious adverse consequences for economic development [Kregel, 1996; Singh, 2001].

These considerations suggest that to avoid financial fragility the government would need to monitor and regulate the amount and timing of FDI. Since the nature of large FDI projects (whether or not for example these would produce exportable products, or how large their imports would be) can also significantly affect the time profile of aggregate foreign exchange inflows and outflows, both in the short and long term, the government may also need to regulate such investments. To the extent that the PMAI would not permit this kind of regulation of FDI, it would subject developing economies to much greater financial fragility.

It could in principle be argued that even if the financial fragility point is conceded, a PMAI may still benefit developing countries by generating greater overall FDI, which could compensate for the increased financial fragility. The validity of this proposition, however, is doubtful. We saw earlier that FDI has risen significantly in the 1990s. This occurred without any MAI and was clearly a product of a number of other factors. ${ }^{18}$ Similarly, regulatory constraints on FDI and the total amount of FDI that a country is able to attract do not appear to be related. Malaysia [U.S., 1996] and China, [Braunstein and Epstein, 1999], for example, are large recipients of FDI despite having significant control and regulation over FDI projects.

\section{FDI AND REAL ECONOMY, TECHNOLOGY TRANSFER, SPILLOVERS, INVESTMENT AND SAVINGS}

Apart from FDI as a source of finance, two of the most important ways in which a developing country may benefit from such investments is (a) through transfer of technology and (b) from spillovers. The latter refer to the effects of FDI on raising productivity in local firms. These firms may be helped by foreign investment in a variety of ways, including the demonstration effect of the new technology and the enhancement of the quality of inputs which such investment may promote. On the other hand there may be few positive or even negative spillovers, if FDI forces local firms out of the market because of greater competition.

Both issues of technology transfer and spillovers have been widely studied, resulting in a large and controversial literature. The main lesson it provides in relation to the question of technology transfer is that a country is more likely to benefit from multinational investment if FDI is integrated into its national development and technological plans [Dunning, 1994; Freeman, 1989; Milberg, 1999; South Centre, 2000]. 
EASTERN ECONOMIC JOURNAL

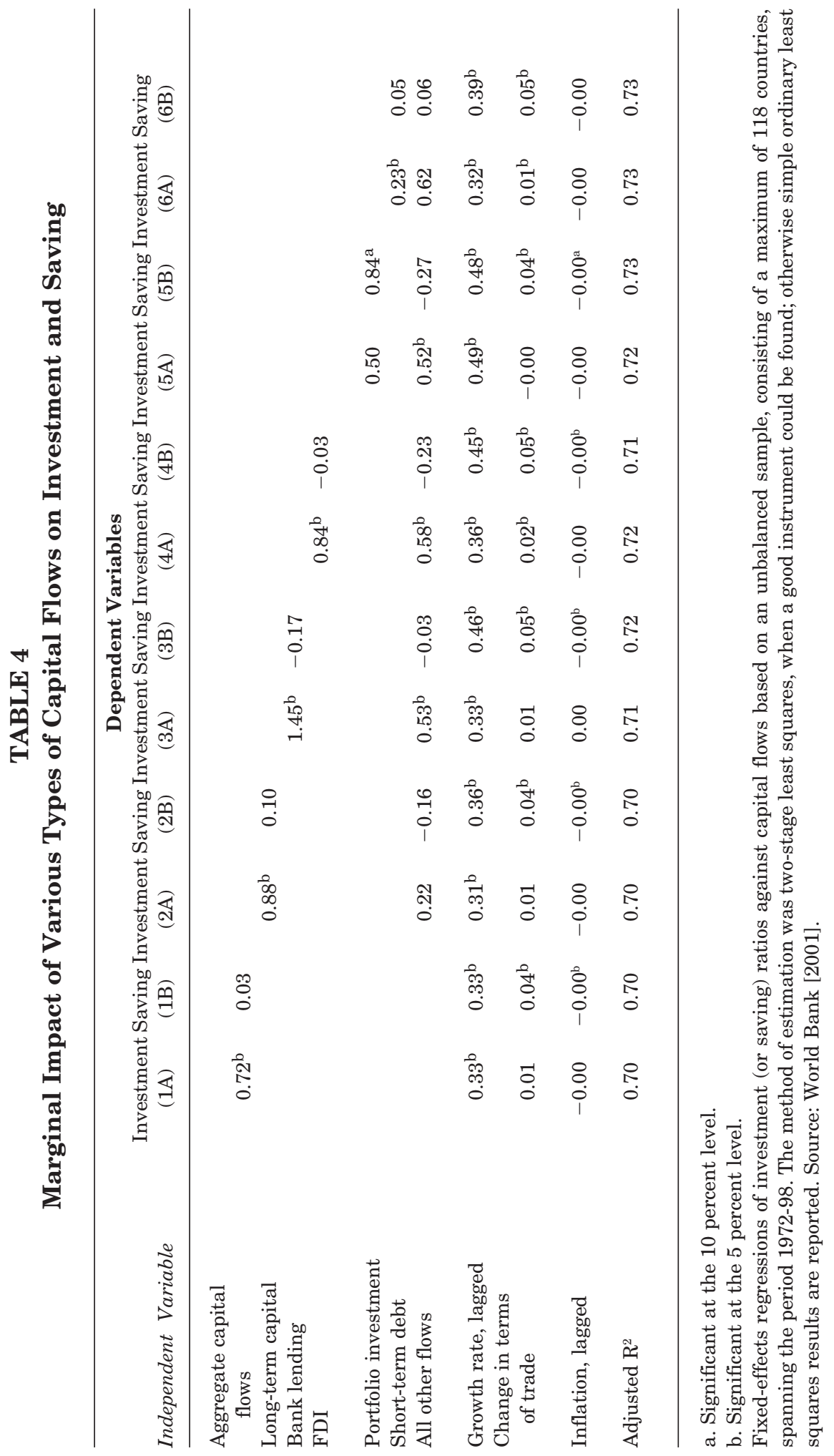


This is why, other than Hong Kong, most successful Asian countries (including China and Malaysia as seen above) have extensively regulated FDI.

On the issue of spillovers, early studies were quite optimistic about the positive externalities from FDI on domestic industries. However, these studies suffered from severe methodological difficulties particularly in relation to the question of causation. More recent research using more up-to-date methodology as well as large microeconomic data sets arrives at much more pessimistic conclusions. In an influential study, Aitken and Harrison [1999] found that in Venezuela multinational investment had a negative effect on productivity of domestic plants in the industry. Such results are quite common from micro-level data [Hanson, 2001]. Similarly, the World Bank reaches the following conclusion from its comprehensive survey of the empirical studies of the effects of FDI on productivity growth in developing countries:

The productivity benefits of capital flows-through the transfer of technology and management techniques and the stimulation of financial sector development-are significant in countries where a developed physical infrastructure, a strong business environment, and open trade regimes have facilitated the absorption of those flows, but not otherwise. (Italics added). [2001, 59]

A critical issue in evaluating the effects of FDI on the real economy is its impact on domestic savings and investments. Economic theory does not yield any unambiguous predictions about how domestic investment may be affected by foreign capital inflows. In general, this depends on the level of development of the economy, its degree of integration with international economy and its absorptive capacity. Table 4 shows the results of World Bank's analysis of the impact of various types of capital flows on investments and savings for a large cross-section of developing countries from 1972 to 1998 . The results show that although FDI is positively associated with the investment, there is little relationship with savings. The long-term bank lending has a more important influence on investment than does FDI. Portfolio investment is, on the other hand, associated more with savings than with investments.

A more interesting analysis of this issue is reported in the recent study by Agosin and Mayer [2000]. This study examines the regional variations in the effects of FDI on the crowding in and out of domestic investment. The two authors' research covered 1970 to 1996 and included host countries from all three developing regionsAfrica, Asia and Latin America. The results of the econometric exercise suggest that over this long period there was strong crowding in in Asia, crowding out in Latin America and more or less neutral effects in Africa. Agosin and Mayer conclude:

...the most far-reaching liberalizations of FDI regimes in the 1990s took place in Latin America, and that FDI regimes in Asia have remained the least liberal in the developing world... Nonetheless, it is in these countries that there is strongest evidence of CI (crowding in). In Latin America, on the other hand,...liberalization does not appear to have led to CI. [ibid., 14] 
Turning finally, but for reasons of space, extremely briefly, to the relationship between FDI and long-term economic growth, Lipsey's comprehensive survey succinctly sums up the evidence on this issue as follows:

... As with the studies of wage and productivity spillovers, those of the effects of FDI inflows on economic growth are inconclusive. Almost all find positive effects in some periods, or among some group of countries, in some specifications, but one cannot say from these studies that there are universal effects. There are periods, industries, and countries where FDI seems to have little relation to growth, especially when other factors, mostly related to FDI also are included as explanations. [2001, 56-57]

What can be concluded for PMAI from the above analysis of various aspects of FDI? The main implication would appear to be that a global regime of unfettered FDI would not be Pareto-optimal for all developing nations. Countries have different (a) levels of economic development, (b) previous history, (c) endowments, (d) path trajectories, and (e) public and private sector capabilities of making effective use of FDI. Some may benefit from unrestricted FDI inflows and may have the absorptive capacity to cope with FDI surges and famines. Others may benefit more from its purposive regulation to avoid coordination or other market failures arising from unfettered FDI, as outlined above. A regime of unrestricted capital flows as envisaged in PMAI would deprive countries of policy autonomy in this sphere. In some cases, for example countries with ineffective or weak governments, this may not matter. However, in other countries regulation of FDI would bring net benefit because the correction of market failures would easily outweigh government failures. The so-called " developmental states" in Asia have been obvious examples of this. The PMAI would not serve the developmental needs of these countries. The main message of this paper is, therefore, that in the real world of second best, a case by case approach and selectivity is called for rather than a one-size-fits-all universal rules of the kind contained in PMAI.

\section{CONCLUSION}

The first part of the paper examined the theoretical and empirical case for shortterm capital account liberalization in developing countries and found it wanting. Indeed, as Stiglitz suggests, there is arguably a compelling case against it. The second part considered the question of long-term capital account liberalization, specifically, that of FDI. Most economists, including Stiglitz, favor such capital flows into developing countries. On closer analysis, however, it is argued here than even FDI, if unregulated, may do more harm than good to many countries. It is therefore suggested that developing countries should resist the new multilateral agreement on investment, which Japan and the EU are proposing at the WTO, even though it will cover only FDI. 


\section{NOTES}

I am grateful for helpful comments from Philip Arestis as well as from session participants at the EEA meeting in Boston in March 2002. Since I could not attend the meeting, Philip kindly presented an earlier version of this paper on my behalf. That I am also indebted to Joseph Stiglitz's writings on the subject, despite important disagreements, will be clear from the paper. It is also a pleasure to record my gratitude to the editor and the four referees of this Journal, whose sometimes fierce comments greatly helped to improve the paper. This work was carried out at the Centre for Business Research at Cambridge University. The Centre's contributions are gratefully acknowledged. The usual caveat applies.

1. For a comprehensive survey and a recent contribution, see for example Feldstein [2002].

2. This section of the paper draws on Chakravarty and Singh [1988].

3. Such a mechanism, for example, existed in the "Golden Age" of the post-WWII era (1950-1973) when, under the aegis of a single hegemonic economic power, namely the U.S., European economies were able to maintain high levels of aggregate demand to ensure full employment [Glyn et al., 1990; Singh, 1995a].

4. See further Freeman [1989]; Singh [1995b]; Amsden [2001].

5. The US was willing to open its own markets to East Asian manufacturers without insisting on reciprocal opening of East Asian market. See further, Glyn et al., [1990].

6. See Passinetti [1981] for a fuller discussion of the learning approach to this issue.

7. On this set of issues, see for example, Stiglitz [1994]; Allen and Gale [2000]; Glen, Lee and Singh [2000].

8. A referee has objected that since Kaminsky and Reinhart [1999] and Demigüc-Kunt and Detragiache [1998] include both developing countries and advanced countries, it is not legitimate to draw conclusions about developing countries alone from this evidence. However, as argued in the text below, developing countries are more prone to financial crises following liberalization than Acs. Considering the two group of countries together will underestimate the strength of the relationship between financial liberalization, banking and currency crisis and underdevelopment rather than to overstate it.

9. For fuller discussion of these issues see Singh [2002a]; Jomo [2001]; Singh and Weisse [1999] and Rodrik [2000].

10. IMF [2002, Box 3.4, 126], broadly supports these conclusions.

11. A referee has pointed out that there is a greater difference in volatility between advanced countries and developing countries in terms of trade compared with capital flows. However, changes in terms of trade may be caused either by capital flows or current account balance, or both, as well as other factors. This important issue will not be pursued here.

12. Similar results are reported in IMF [2002].

13. For a fuller discussion of the issues involved in this argument see Cosh, Hughes and Singh [1990] and Singh [2000].

14. This and the following sections are based on Singh [2001].

15. See Singh and Zammit [1998] for a further discussion.

16. This is the empirical definition of FDI adopted by many countries to distinguish it from portfolio flows.

17. A referee has pointed out that the problems of FDI volatility create difficulties not just for developing countries but also for the U.S. where there has been a substantial drop in FDI recently.

18. See Singh [1997a; 1997b]; Singh and Weisse [1998] for a further discussion.

\section{REFERENCES}

Agosin, M. R. and Mayer, R. Foreign Investment in Developing Countries: Does it Crowd in Domestic Investment? United Nations Conference on Trade and Development, Discussion Paper, No. 146. February 2000.

Aitken, B. J., and Harrison, A. E. Do Domestic Firms Benefit from Direct Foreign Investment? Evidence from Venezuela. American Economic Review, June 1999, 605-18. 
Aizenman, J. Financial Opening: Evidence and Policy Options, NBER Working Paper 8900, 2002.

Allen, F., and Gale, D. Comparing Financial Systems. Cambridge, MA: MIT Press, 2000.

Amsden, A. H. The Rise of "The Rest": Challenges to the West from Late-Industriising Economies. New York: Oxford University Press, 2001.

Arrow, K. The Economic Implications of Learning by Doing, Review of Economic Studies, 1962, 155-73.

Bekaert, G., Harvey, C., and Lundblad, C. Does Financial Liberalization Spur Growth? NBER Working Paper No. 8 245. Cambridge: MA: National Bureau of Economic Research, 2001.

Bhagwati, J. The Capital Myth: The Difference Between Trade in Widgets and Trade in Dollars, Foreign Affairs, 1998, 7-12.

Borensztein, E., Giorgio, J. De. and Lee, J-W. How does Foreign Investment Affect Growth? Journal of International Economics, June 1998, 115-35.

Braunstein, E. and Epstein, G. Towards a New MAI. In Jonathan Michie \& John Grieve Smith (Eds.) Global Instability and World Economic Governance. NY: Routledge, 1999.

Caprio, G., and Klingebiel, D. Bank Insolvencies: Cross-Country Experience. World Bank Policy Research Working Paper 1620. Washington, DC: 1996.

Chakravarty, S. and Singh, A. The Desirable Forms of Economic Openness in the South. Helsinki: World Institute for Development Economics Research, 1988.

Chang, H.-J., ed. Joseph Stiglitz and the World Bank: The Rebel Within. London. UK: Anthem Press, Wimbledon Publishing Company, 2001.

Chari, A. and Henry, P. Capital Account Liberalization: Allocative Efficiency or Animal Spirits?, NBER Working Paper 8908, 2002.

Claessens, S., Dooley, M. and Warner, A. Portfolio Capital Flows: Hot or Cool?, World Bank Economic Review, 1995, 153-174.

Cosh, A. D., Hughes, A. and Singh, A. Takeovers and Short Termism: Analytical and Policy Issues in the UK Economy. In Takeovers and Short Termism in the UK, Industrial Policy Paper No, 3, Institute for Public Policy Research, London, 1990.

Davidson, P. If Markets are Efficient, Why Have There Been So Many International Financial Market Crises Since the 1970s? in What Global Economic Crisis? edited by P. Arestis, M. Baddeley and J. McCombie. NY and UK: Palgrave, Hampshire, 2001.

Demetriades, P. O. and Luintel, K. B. Financial Restraints in the South Korean Miracle, Journal of Development Economics, April 2001, 459-79.

Demigüc-Kunt, A., and Detragiache, E. Financial Liberalization and Financial Fragility. In Proceedings of Annual Bank Conference on Development Economics, Washington, DC, April 1998, 20-21.

Dunning, J. Re-evaluating the Benefits of Foreign Direct Investment. Transnational Corporations, February 1994, 23-52.

Easterly, W., Islam, R., and Stiglitz, J. E. Shaken and Stirred: Explaining Growth Volatility, in Annual World Bank Conference on Development Economics, The International Bank for Reconstruction and Development, edited by B. Pleskovic and N. Stern. The World Bank, 2000, 191-211.

Eatwell, J. International Financial Liberalization: The Impact on World Development, ODS Discussion Paper Series, No. 12. New York: UNDP, 1996.

Edison, H., Levine, R., Ricci, L., and Slok, T. Capital Account Liberalization and Economic Performance: Survey and Synthesis, IMF Working Paper, 02/120, 2002.

Feldstein, M. Economic and Financial Crises in Emerging Market Economies: Overview of Prevention and Management. NBER Working Paper Series, Working Paper 8837, Cambridge, MA.: 2002.

Fischer, S. Capital Account Liberalization and the Role of the IMF. Paper presented at the seminar Asia and the IMF, held in Hong Kong, China: IMF, 19 September 1997.

. On the Need for an International Lender of Last Resort. Journal of Economic Perspectives, Fall 1999, 85-104.

Freeman, C. New Technology and Catching Up. European Journal of Development Research, 1/1, 1989.

Friedman, M. Essays in Positive Economics. Chicago: University of Chicago Press, 1953.

Furman, J., and Stiglitz, J. E. Economic Crises: Evidence and Insights from East Asia. Brookings Papers on Economic Activity, 2, Brookings Institution, Washington, DC, 1999a.

Glen, J., Lee, K., and Singh, A. Competition, Corporate Governance and Financing of Corporate Growth in Emerging Markets. Cambridge Discussion Papers in Accounting and Finance, AF46. Department of Applied Economics, University of Cambridge. Cambridge, 2000.

Glyn, A., Hughes, A., Lipietz, A., and Singh, A. The Rise and Fall of the Golden Age, in The Golden Age of Capitalism, edited by S. A. Marglin and J. B. Schor. Oxford: Oxford University Press, 1990. 
Greenspan, A. Risk Mangement in the Global Financial System. Speech delivered to the Annual Financial Markets Conference of the Federal Reserve Bank of Atlanta, Miami Beach, Florida, 27 February 1998.

Gomery, R. E. and Baumol, W. J. Global Trade and Conflicting National Interest. Cambridge, Massachusetts: MIT Press, 2000.

Hanson, G. H. Should Countries Promote Foreign Direct Investment?, G-24 Discussion Paper Series, No. 9, New York: UNCTAD, February 2001.

Henry, P. B. Do Stock Market Liberalizations Cause Investment Booms? Journal of Financial Economics, 2000, 301-334.

Jomo, K. S. Growth After the Asian Crisis: What Remains of the East Asian Model? G-24 Discussion Paper Series, No. 10, United Nation Conference on Trade and Development. Centre for International Development Harvard University. United Nations, New York and Geneva, March 2001.

Kaldor, N. Further Essays on Economic Theory. London: Duckworth, 1978.

Kaminsky, G. L. and Reinhart, C. L. The Twin Crises: The Causes of Banking and Balance-of-Payments Problems. American Economic Review, 1999, 473-500.

Kaufman, H. On Money and Markets: A Wall Street Memoir. New York: McGraw Hill, 2000.

Keynes, J. M. The General Theory of Employment Interest and Money. New York, Harcourt, Brace and Company, 1936.

Kindleberger, C. P. A Financial History of Western Europe. London: George Allen and Unwin, 1984.

Kregel, J. A. Some Risks and Implications of Financial Globalisation for National Policy Autonomy. UNCTAD Review, United Nations, Geneva, 1996.

Krugman, P. R. Is Free Trade Passé?, Journal of Economics Perspectives, 1987, 131-43.

Lipsey, R. E. Foreign Direct Investors in Three Financial Crises. NBER Working Paper, No. 8084, 2001.

Loungani, P. Capital Flows. IMF Research Bulletin, September 2002, 1-3.

Martin, P. and Rey, H. Financial Globalization and Emerging Markets: With or Without Crash? NBER Working Paper 9288, 2002.

McKinnon, R. and Pill, H. Exchange-Rate Regimes for Emerging Markets: Moral Hazard and International Over-borrowing. Oxford Review of Economic Policy, 1999.

Mendoza, E. Credit, Prices and Crashes: Business Cycles with a Sudden Stop, NBER Working Paper 8338, 2001.

Milberg, W. Foreign Direct Investment and Development: Balancing Costs and Benefits. International Monetary and Financial Issues for the 1990s, United Nations Conference on Trade and Development, 1999, 99-115.

Mody, A. and Murshid, A. P. Growing Up with Capital Flows. IMF Working Paper No. 02/75, 2002.

Moggridge, D. The Collected Writings of John Maynard Keynes, Vol. XXV. Cambridge: Cambridge University Press, 1980.

Occampo, J. A. Rethinking the Development Agenda. Economic Commission for Latin America and the Caribbean. United Nations, 2001.

Occampo J. A. and Taylor, L. Trade Liberalization in Developing Economies: Modest Benefits But Problems with Productivity Growth, Macro Prices, and Income Distribution, in Controversies in Macroeconomics Growth, Trade and Policy, edited by H.D. Dixon. Massachusetts: Blackwell, 2000.

Pasinetti, L. L. Structural Change and Economic Growth. Cambridge: Cambridge University Press, Chapter 11.

Pindyck, R. S. Irreversibility, Uncertainty and Cyclical Investment. Journal of Economic Literature, 1991, 1110-48.

Rakshit, M. K. Globalization of Capital Markets: Some Analytical and Policy Issues, in Globalisation and Economic Development, Essays in Honor of Waardenburg, edited by S. Storm. Naastepad, UK, MA, U.S.A.: Edward Elgar, 2001.

Ramey, G., and Ramey, V. Volatility and Growth. American Economic Review, 1995, 559-86.

Rodrik, D. Development Strategies for the 21st Century, in Annual World Bank Conference on Development Economics 2000. International Bank for Recontruction and Development, The World Bank, 2000, 85-124.

Shiller, R. J. Irrational Exuberance. Princeton, NJ: Princeton University Press, 2000.

Singh, A. The Causes of Fast Economic Growth in East Asia. UNCTAD Review, Geneva, 1995a, 91-127. . Institutional Requirements for Full Employment in Advanced Economies. International Labour Review, 1995b. 
- Liberalization and Globalization: An Unhealthy Euphoria, in Employment and Economic Performance: Jobs, Inflation and Growth, edited by J. Michie and J. G. Smith. New York: Oxford University Press, 1997a, 11-35.

- Financial Liberalisation, Stockmarkets and Economic Development. The Economic Journal, Oxford, UK and Boston, U.S.A.: Blackwell Publishers, May 1997b, 771-82.

. Should Africa Promote Stock Market Capitalism? Journal of International Development. 1999, 343-65.

- The Anglo-Saxon Market for Corporate Control: The Financial System and International Competitiveness, in Competitiveness Matters: Industry and Economic Performance in the U.S., edited by C. Howes and A. Singh. Ann Arbor, MI: The University of Michigan Press, 2000.

. Foreign Direct Investment and International Agreements a South Perspective. Occasional Paper, Trade-Related Agenda, Development and Equity. South Centre, October 2001.

- Asian Capitalism and the Financial Crisis, in International Capital Markets: Systems in Transition, edited by J. Eatwell and L. Taylor. Oxford University Press, Inc. 2002, 339-67.

Singh, A. and Weisse, B. A. The Asian Model: A Crisis Foretold. International Social Science Journal; 1999, 203-215.

Singh, A. and Zammit, A. Foreign Direct Investment: Towards Cooperative Institutional Arrangements between the North and the South, in Globalisation, Growth and Governance, edited by J. Michie and J. Grieve-Smith. Oxford: Oxford University Press, 1998.

. International Capital Flows: Identifying the Gender Dimension. World Development. 2000, 1249-68.

South Centre. Foreign Direct Investment, Development and the New Global Economic Order: A Policy Brief for the South. Geneva: South Centre. 2000.

Stiglitz, J. E. Reforming the Global Economic Architecture: Lessons from Recent Crises. The Journal of Finance, 1999, 1508-21. 1075-86.

Summers, L. International Financial Crises: Causes, Prevention and Cures. American Economics Review Papers and Proceedings, May 2000, 1-16.

United Nations. Trade and Development Report. Geneva, Switzerland: UNCTAD 1998, 2000, 2001

Williamson, J. and Drabek, Z. Whether and When to Liberalize Capital Account and Financial Services. Staff Working Paper ERAD-99-03. World Trade Organization. Economic Research and Analysis Division. 1998.

Williamson, J. Proposals for Curbing the Boom-Bust Cycle in the Supply of Capital to Emerging Markets. Discussion Paper No. 2002/3. Helsinki: United Nations University, World Insitite for International Development Economics Research (WIDER), 2002.

World Bank. Global Development Finance: Building Coalitions for Effective Development Finance. Washington, DC: The World Bank, 2001.

. World Development Report: Knowledge for Development (1998/99). Washington, D.C. The World Bank, 1999.

Wyplosz, C. How Risky is Financial Liberalization in the Developing Countries? CEPR DP 2724. 2001.

Young, A. A. Increasing Returns and Economic Progress. Economic Journal, 1928, 527-42. 